NASATECHNICAL MEMORANDUM

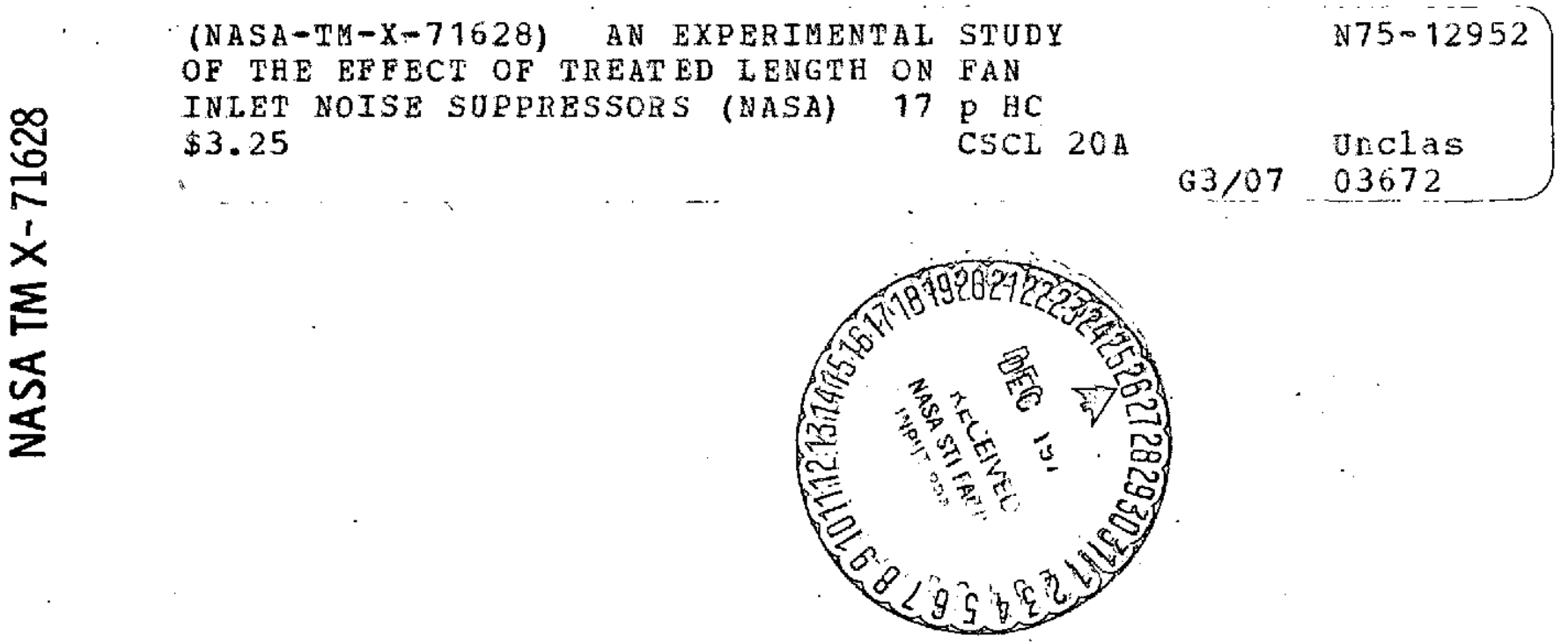

\title{
AN EXPERIMENTAL STUDY OF THE EFFECT_OF TREATED LENGTH ON FAN INLET NOISE SUPPRESSORS
}

by James H. Dittmar and John F。Groeneweg

Lewis Research Center

Cleveland, Ohio 44135

TECHNICAL PAPER to be presented at Thirteenth Aerospace Sciences Meeting sponsored by the American Institute of Aeronautics and Astronautics Pasadena, California, January 20-22, 1975 


\author{
James H. Dittmar * and John F. Groeneweg* \\ National Aeronautica and Space Administration \\ Lew1s Research Center \\ cleveland, Ohto
}

\section{Abstract}

An experimental study of the effect of length of acoustic treatment was performed on a full acale fan using two different inlets. Analysis of the data revealed that measured suppression varted Inearly with the length of the ringed liner segments as anticlpated. Further analysis indicated that the wall only portion of the treatment was substantially more effective than antlcipated suggesting that, if only moderate suppression is needed, wall only treatment may suffice. Contrary to expectation the two inlets behaved simflarly. Introduction of a hard exhaust splitter into the configuration resulted In a noise Increase at certain frequencies.

\section{Introduction}

The use of amall amounts of nolse suppresston material is common in commercial turbofan engines to meet present noise standards (FAR 36). However, the use of substantially greater amounts of treatment is contemplated to meet anticipated, more severe, future nolse requirements. The length and associated welght of this sound absorbing material are significant constderations in engine and necelle design. To increase the knowledge of inlet suppresaor performance with length variation, the full-scale fan tests described in this report were conducted.

Two exdsting inlet nolse suppressors were tested in an outdoor nolse facility at Lewls, described in references 1 and 2. The suppressors were designed using the theory described in references 3 and 4 . These suppressors were of a perforated-plate-over-honeycomb congtruction and Included wall treatment as well as three treated splitter ringe. The differences between the two suppressors were in the open area and hole size of their faoing sheets. The attenuation charecterlotics of the suppressors were expected to differ primarily in level.

The suppressors were installed in the Inlet duct of a 1.4 pressure rat1o, 1.83 meter ( $6 \mathrm{ft}$ ) diameter fan stage. Sound power level attenuation increments were measured for three treated lengths of each suppressor by selectively removing metal tape from the lined gurfaces. The fan exhaust duct, Including an aft splitter, was acoustically treated for these tests to minimize forward radiation of aft fan noise that could mask the performance of the inlet suppressor. Tests were run with and without a taped exhaust splitter to determine If notse was generated by adding the splitter to the exhrust duct.

In order to evaluate the performance of the suppressors, comparisons were made of the nolse reductions from the experiments and the design theory. These comparisons were made both for the

\footnotetext{
*Aerospace Englneers, v/STOL and Nolse Division.
}

total noise reduction of the fully active suppressors and for the variation of the nolse reduction with length. In go doing, information was obtained about the performance of the outer cowl wall and splitter ring portions of the inlet suppressors.

\section{Apparatus and Procedure}

Test Fac1lity and Instrumentation

The experiments reported herein were conducted In the full-gcale fan outdoor test facility at Lewis.1,2 F1gure 1(a) shows the test site, and Elgure 1(b) shows a plan view of the test facility. Acoustic data were obtalned by 1.27 centimeter ( 0.5 in:) condenser microphones located at 10 degree increments from 10 to 160 degrees as shown in figure $1(\mathrm{~b})$. The microphones were level with the fan centerline, 5.79 meters (19 ft) above the ground on a 30.48 meter $(100 \mathrm{ft})$ radius.

A cutaway view of the 1.83 meter (6 ft) diameter fan assembly used in these tests is shown in figure 2. This single-stage fan had a large rotor stator axial spacing of approximately 3.7 rotor chords and had no inlet guide vanes. The fan had 53 rotor and 112 stator blades. The noise data were taken at four fan operating conditions corresponding to $60,70,80$, and 90 percent design speed. Three sets of data were taken at each test condition to average out the short term fluctuathons in the generated nolse.

\section{Suppressors}

Two Inlet noise suppressors were used in the itner length variation tegts. The inlet suppressors consisted of a lined outer cowl and three 2.54 centimeter ( 1 in.) thick, splitter rings with acoustic lining on both sides of the rings (f1g. 2). The suppressor dimensions and the materlals used in the acoustic liners are shown in figure 3. As indicated in figure $3(a)$, the two inlet suppressors (destgnated suppressors $A$ and B) differed. only with respect to facing sheet open area ratio and hole size. The intent in testing the two ouppressors was to compare the attenuation performance for the two combinations of facing sheet resiatance. Suppressor $B$ was the same auppressor used in the tests reported previously in reference 3. A fully active exhaust suppressor was installed during the inlet suppressor length tests to minimize forward-radiated aft fan notse that might otherwise have masked the results. The exhaust suppressor dimensions and the materials used in the acoustic liners are shown in figure $3(b)$.

These inlet and exhaust suppressors were designed based on the theory of references 3 and 4 . The liners were constructed w1th a perforated aluminum facing sheet bonded to an aluminum honeycomb backing. Different honeycomb backing thicknesses (different surface number) were used on opposing walls of a passage to broaden the frequency range of the nolse attenuation. 
The inlet suppressors were tested at three treated lengths by selectively removing metal tape from the lined surfaces. The length increments were chosen so that the shortest treated length in each passage was broken into equal parts as shown in figure 4. This selection was to make the length of liner with active walls facing each other equal in each section for a given passage. As can also be seen In this figure, the segment of liner passage closest to the fan had additional materlal which extended downstream on the outer surface of each passage and was not opposed by a treated surface.

The baseline configuration against which inlet suppressor length variations were compared was the fully taped inlet including splitter rings and fully active exhaust suppressor (flg. 3(b)). Inlet suppressor segments were activated in three successlve steps of tape removal beginning with the segment nenrest the fan. In addition to the inlet treatment runs, totally taped conflgurations were run with and without the taped exhaust splitter.

\section{Results and Discussion}

\section{Sound Power Levei Spectra}

The sound power spectra obtained for the inlet hemisphere are shown in flgure 5 for suppressors $A$ and $B$ at the 90 and 60 percent speeds. These speeds roughly correspond to the speed of the fan in an engine at conditions for takeoff (90\%) and landing (60\%). Four spectra are shown on each plot of figure 5 , for the taped inlet, the downstream segment nearest the fan active, downstream and middle segments active and the fully active suppressor configurations. All the plots show that activating successive inlet treatment increments produced reductions over a wide range of frequencies Including the blade passage frequency. However, at frequencies less than 1000 hertz, reduction occurred with the activation of the downstream liner segment, but no appreclable reductions occurred when the middle and upstream increments were added. This indicates the possible existence of a nolse floor at the lower frequencies. A posstble cause of this notse floor is discussed later in the exhaust suppressor section.

The corresponding inlet hemisphere sound power level attenuation spectra obtained by taking the differences between the taped and the treated Inlet spectra of figure 5 are shown in figure 6. Peak attenuations occur in the one-third octave bands contalning the blade passage frequencies which in general fall in the 2000 hertz band at 60 percent speed (figs. 6(b) and (d)) and the 3150 hertz band at 90 percent apeed (figs, 6(a) and (c)). Shifts In the one-third octave band having maximum attenuation occur due to the varlation in fan physical speed set on dffferent days to maintain constant corrected speed. In all cases, exposure of the first segment of the Iner yielded larger attenuations than that produced by uncovering the other two gegments.

\section{Analysis}

Attenuation spectra, A number of calculations were performed to compare the suppression theory with the experimental data. These attenuation cal- for the fully active length of suppressors $A$ and $B$ at both 60 and 90 percent speed. The calculations, made for an 1nlet Mach number of 0.23 for 60 percent and 0.35 for 90 percent speed, resulted in the curves presented in figure 7 . The attenuation data for the two suppressors are also shown in these plots.

Beyond 2000 hertz the measured attenuations were greater than the predicted values. This behavior was also observed in the data obtained with suppressor $B$ on a different fan. ${ }^{3}$ The predicted curves also peak at a lower frequency than the measured data. As previously mentioned, the measured attenuations peaked at the blade passage tone in all of the configurations. This behavior has also occurred with suppressor $B$ on two other fans where the blade passage frequencies were significantly different than for the fan tested herein but where the predicted frequency of peak attenuation was approximately the same for all three fans, 5,6 This behavior indicates that the liner may remove sound selectively at the blade passage tone and therefore a modification of the liner prediction to separately handle the attenuation at the blade passage tone may be necessary.

As is also shown by ffgure 7, the experimental behavior of suppressors $A$ and $B$ is quite similar In the fully active condition. This similarity was also true in the partly taped configurations. Although the predicted curves are signiflcantly different for these two suppressors, the experimental varlations are roughly equivalent. This behavior was unexpected and unexplained in terms of the propagation and impedance models.

Varlation with length. The greater effectiveness of the liner segment nearest the fan relative to the other two ringed-passage segments was mentioned previously and is probably related to the presence of the additional unopposed will treatment between the ring trailing edges and the fan face. As shown in figure 4, the most signiflcant portion of this additional treatment is the 61-centimeter (24 in.) length on the outside wal1. If the ringed portions of all three length segments are assumed to perform simtlarly, 1t is posstble to break the inlet attenuation into two parts: one corresponding to the ringed portion of the inlet; and the other to this segment of outside wall only treatment. To accomplish the separation, the inlet power level reduction at 90 percent speed is plotted In figure 8 as a function of the fraction of the ring length which is actlve. The curves shown are for the one-third octave bands containing, the blade passage tone, broad band nolse at 5000 hertz and the first overtone of the blade passage tone. The variation of the sound power level reduction with treated length inside the rings was almost linear as expected from the theory.

Wa11 treatment attenuation. If the observed linear variation of the sound power level reduction with treated length is assumed to hold for the ringed part of the liner segment nearest the fan, the curves can be linearly extrapolated to zero active ring length to reveal the effect of the initial 61 centimeters $(24 \mathrm{in}$.) of outer wall treatment. This $1 \mathrm{~s}$ done in figure 9 at the blade passage frequency for each suppressor. Here it is seen that the intercept is $7 \mathrm{~dB}$ for suppressor $A$ 
and $5 \frac{1}{2} \mathrm{~dB}$ for suppressor $B$. Theae intercepts are interpreted to be the attenuation provided by the initial segment of unopposed outer wall treatment

The peak attenuation attributed to this outer wall segment may be compared with the theoretical maxima calculated from the theory of reference 3 which assumes a plane pressure wave as an initial condition. Theoretical maximum curves of $\triangle d B /(L / H)$ are platted against the frequency parameter, $\mathrm{HF} / \mathrm{C}$, in Elgure 10 . Here, $\Delta \mathrm{dB}$ is the sound power attenuation, $L$ is the length of acoustic treatment, $H$ is the duct height between treated surfaces, $f$ is the frequency of the maximum at tenuation, and $C$ is the speed of sound. Data points corresponding to the Intercepts in figure 9 are also shown in figure 10 at a value of $\mathrm{Hf} / \mathrm{C}=9.94$. Frequency, $f$, was taken as the blade passage frequency at approximately 2800 hertz, the passage height, $\mathrm{H}$, was twice the average helght between the treated cow 1 wall and the hard centerbody and the treated length $\mathrm{L}$ was 61 centimeters. Figure 10 shows that the experimental attenuations are much greater than the theory indicates to be possible, This inordinate effectiveness of the cylindrical cowl treatment has been observed in other experiments (e.g., ref. 7) and a sumary of recent observations on this phenomena is found in reference 8 .

The large discrepancy between maximum predicted and measured attenuation at large values of the frequency parameter indicates a need to modify the duct propagation theory to correctly handle this case. One possible explanation for this 1ncreased attenuation compared with the plane wave theory is found in a paper by Rice. ${ }^{9}$ This paper indicates the possibility of Increased attenuation when spinning modes are present in a circular fan duct. In a practical sense, the Increased attenuation observed points to the possibillty of using no-ring inlet configurations (wall treatment only) in cases where the noise reduction requirements are moderate.

Ringed treatment attenuation. - When the sound power attenuation attributed to the unopposed outer wall treatment is subtracted from the total attenuation, an estimate of the attenuation due to the ringed part results. The extrapolation procedure 111 ustrated in figure 10 was carried out at additional frequencies so that the subtraction process just described could be used to arrive at approximate attenuation spectra for the ringed portions of the suppressor. The results are compared to the acoustical predictions in flgures 11 (a) and (b) for 90 and 60 percent speed, respectively. The theoretical curves are the same as in flgure 7 since the theory Indicated that the unopposed outer wall treatment would not contribute signiflcantly to the atcenuation predicted.

The ringed portion attenuations shown in figure 11 are st1l1 above the predicted curves at frequencies greater than the blade passage frequency but they are closer than were the total attenuations shown in figure 7. The attenuation stili appears to peak near the blade passage tone with some slight variation in frequency because of physical fan apeed varlation from run to run as mentioned before. The general shapes of the predicted and extrapolated curves in figure 11 are simflar, except that the peak is at a higher frequency than predicted and the measured suppression is lower.
Aspects of the theory that address this discrepancy and are candidates for Investigation and possible revision include the wall impedance model, the acoustic profile and modal structure generated by the fan and the manner in which passage attenuations are combined. It should also be borne in mind that the data for the ringed passages were obtained by a 1inear extrapolation assumption. Which of these factors is primarily responsible for the observed discrepancy is presently an open question.

\section{Exhaust 'Splitter}

The sound power level spectra shown in figure 5 indicated the possibility of a nolse floor which limited the attainable suppression in the low frequency range of the spectra. Some light on this nolse floor was shed by tests with and without the exhaust duct splitter (fig. 1).

The results of adding a taped exhaust splitter to the totally taped configuration including taped inlet rings are shown in figure 12 in terms of inlet and exhaust sound power level spectra. (Eighty percent speed is used because an equipment failure aborted the 90 percent speed run for one of the configurations.) Data from three configurations are superimposed: (1) taped inlet with taped rings and taped exhaust without splitter; (2) taped Inlet with taped rings and taped exhaust with taped splitter; and (3) the fully active inlet suppressor and fully active exhaust with splitter.

As can be seen from flgure 12, the addition of the taped exhaust splitter had little effect on the blade passage tone in elther the inlet or exhaust hemlsphere. However, a significant broadband nolse increase was observed particularly in the 315 to 2000 hertz range. Increases were observed in both hemlspheres but were greatest in the exhaust hemisphere. The probable cause is broadband noise generation associated with high Mach number flow $(M=0.6)$ over the taped exhaust splitter and sup-
port struts.

The treated spectra in figure 12 show that sizable nolse reductions were obtained above 1000 hertz with the fully active suppressor configuration. However, the broadband nolse below 800 hertz was not reduced in the inlet hemisphere (f1g. 12(a)), and, in fact; the noise in the exhaust hems sphere ( $f i_{g} .12(\mathrm{~b})$ ) from about 400 to 800 herta is higher than that of the completely taped inlet conftguration wh1ch had no exhaust splitter. Therefore, making the liner fully active did not remove all of the noise generated by the flow over the taped exhaust splitter. Internally generated nolse by flow over the splitter may' be responsible for the insensitivity of inlet attenuation levels below 1000 hertz to the addition of inlet treatment as mentioned previously. The observation suggests that nolse generated by flow over exhaust splitters may present a floor or limit to the amount of noise reduction achlevable by a particular liner configuration.

\section{Summary of Results}

Two inlet nolse suppressors, each contalning three treated aplitter ringa, were tested on a 1.4 pressure ratio fu11-scale fan. The suppressors were of a perforated-plate-over-honeycomb-backing 
construction and differed in the open area and hole size of the perforated sheet. Sound power attenuations were measured for three treated length segments of each suppressor by successively removing metal tape from the lined surfaces. It was found that:

1. The attenuation resulting from the segment of liner closest to the fan was greater than the attenuation resulting from the activation of either the middle or forward segments. This result is attributable to the fact that the most effectlve segment included an additional length of treatment on the outside wall. The acoustic attenuation of this unopposed cowl wall treatment, as found by extrapolation, is much greater than the maximum predicted by a duct propagation model using a plane wave Inttial condition. Modifled propagation analyses are thus requixed for open Inlets. Moreover, the high effectiveness of cowl treatment points to the possibility of using no-ring inlet configurations in cases where inlet noise reduction requirements are moderate.

2. The two suppressors behaved similarly in spite of different open areas and hole sizes for which the theory predicts different behavior. This unexpected result remalns unexplained.

3. The sound power leve1 attenuations of the ringed portions of the liners were linear with Iiner length, as expected from theory. In most cases, however, the peak attenuations were less than predicted and occurred near the blade passage frequency even though the theory predicted peak attenuations at a different frequency.

4. The addition of a taped exhaust splitter did not affect the blade passage tone significantly, but the broadband nolse was increased in the 315 to 2000 hertz range. This nolse, believed to be generated by flow over the splitter and support struts is probably the noise floor uncovered in the inlet suppressor length experiments. The results Indicate that internal noise generated by the insertion of splitter rings and thefr supports can limit the amount of noise reduction obtainable with a particular suppressor configuration.

\section{References}

1. Leonard, Bruce R.; SchmiedIIn, Ralph F.; Stakolich, Edward G.; and Neumann, Harvey E.: Acoustic and Aerodynamlc Performance of a 6Foot-Diameter Fan for Turbofan Engines. I Design of Facility and QF-1 Fan. NASA TN D$5877,1970$.

2. Goldstein, Arthur W.; Lucas, James G.; and Balombin, Joseph R.: Acoust1c and Aerodynamic Performance of a 6-Foot-Dlameter Fan for Turbofan Engines. II - Performance of QF-1 Fan in Nacelle Without Acoustic Suppression. NASA TN D-6080, 1970.

3. Rice, Edward J.; Feiler, Charles E.; and Acker, Loren W.: Acoustic and Aerodynamic Performance of a 6-Foot-Diameter Fan for Turbofan Engines. III - Performance with Nolse Suppressors. NASA TN D-6178, 1971.

4. Rice, Edward J,: Attenuation of Sound in SoftWalled Circular Ducts. Aerodynamic Notse,
H. S. Rfbner, ed., Univ. Toronto Press, 1969 , pp. 229-249.

5. Montegan1, Francis J.: No1se Generated by Quiet Engine Fans. I - Fan B, NASA TM X-2528, 1972.

6. Montegan1, Francis J.; Schaefer, John W.; and Stakolich, Edward G.: Nolse Generated by Quiet Engine Fans. II - Fan A. NASA TM X3066, 1974.

7. Feller, Charles E,; Groeneweg, John F.; Rice, Edward J.; Smith, Edward B.; and Tucker, Rodger H.: Fan Nolse Suppression. Alrcraft Engine Noise Reduction. NASA SP-311, 1972, pp. 63-102.

8. Feller, Charles E.; and Merriman, James E.: Effects of Forward Velocity and Acoustic Treatment on Inlet Fan Noise. AIAA Paper 74-946, Aug. 1974.

9. Rice, Edward J.: Spinning Mode Sound Propagation In Ducts with Acoustic Treatment. Paper presented at the 88th meeting of the Acoustical Society of America, St. Louls, Missouri, Nov. 1974. 


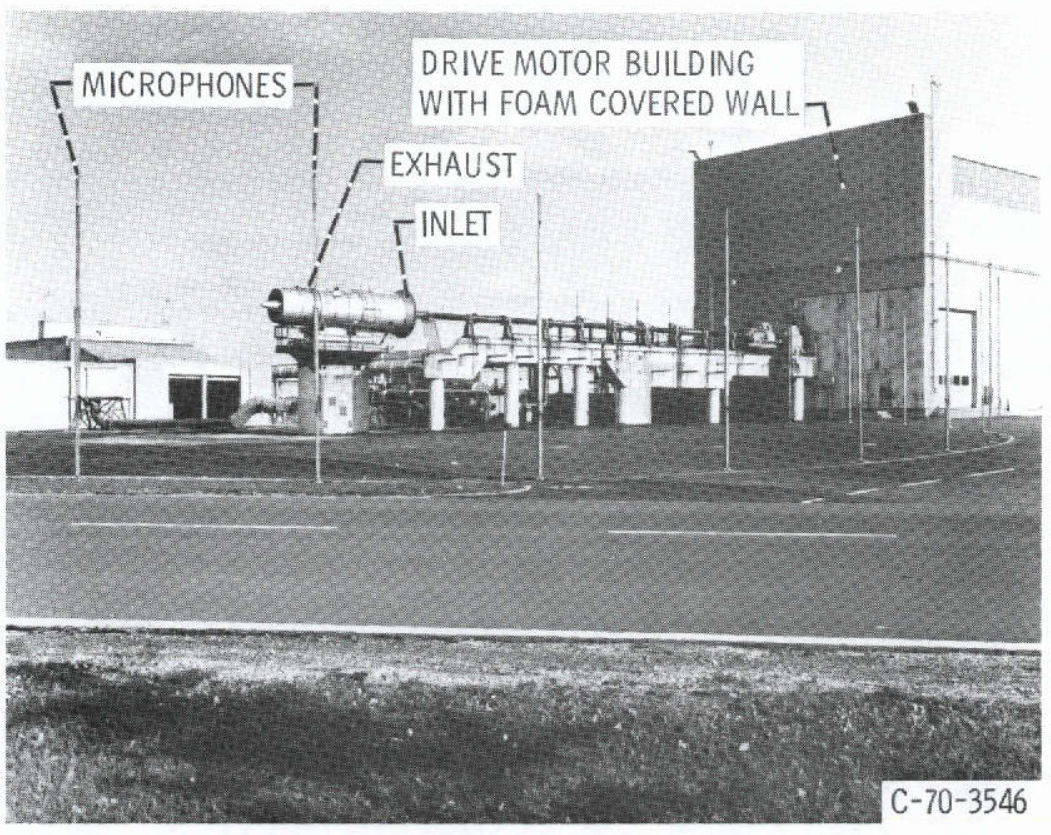

(a) PHOTOGRAPH OF TEST SITE.

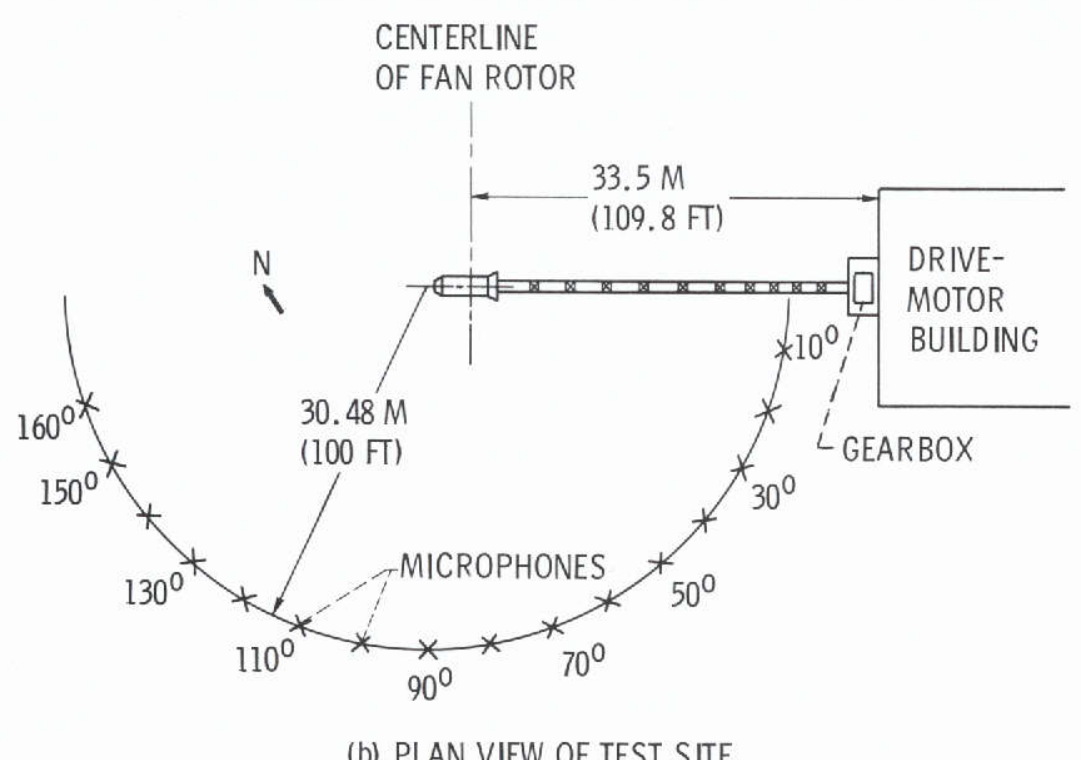

(b) PLAN VIEW OF TEST SITE.

Figure 1. Full-scale fan test facility. 


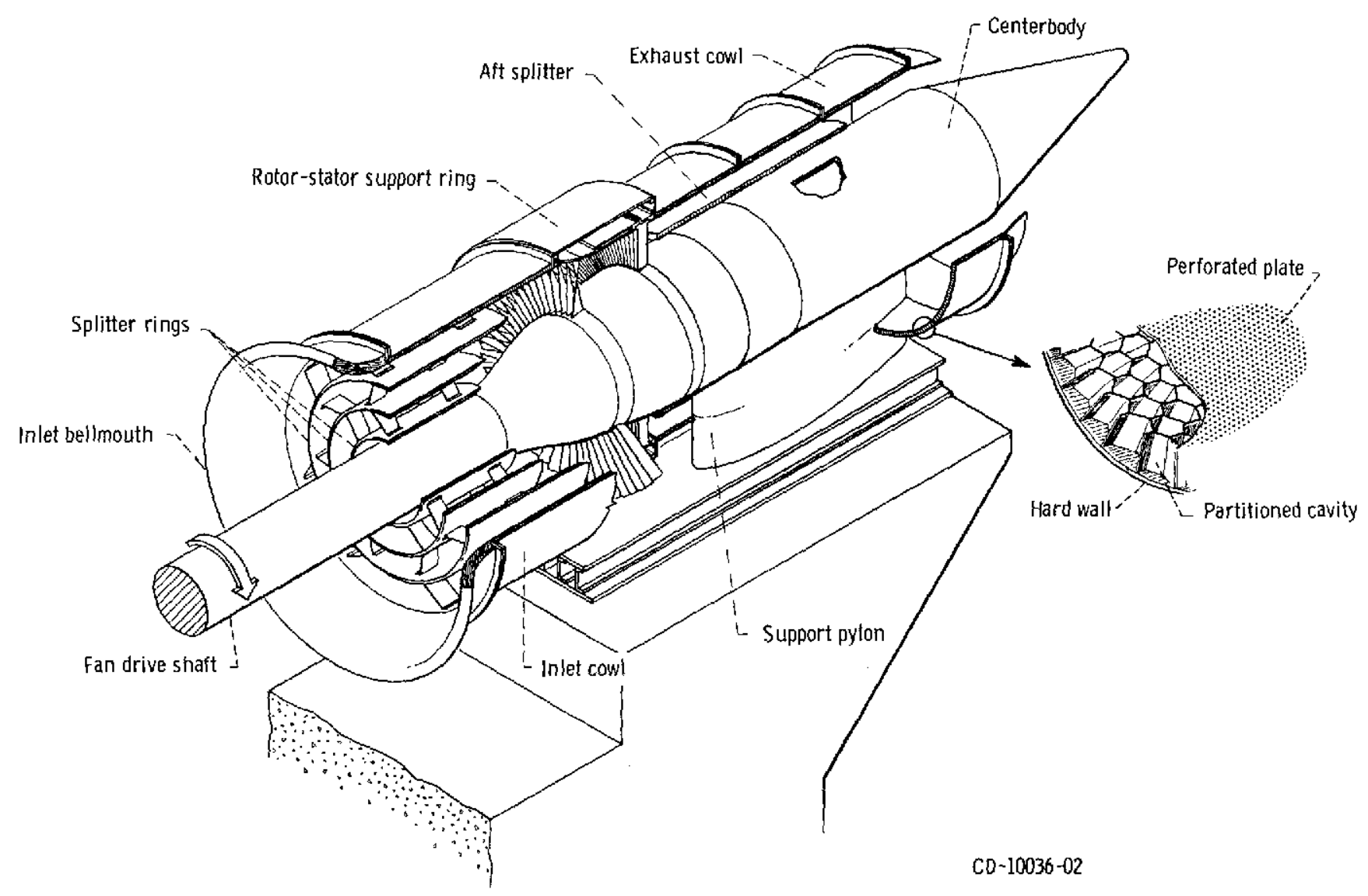

Figure 2. - Cutaway view of fan and suppressor assembly. 


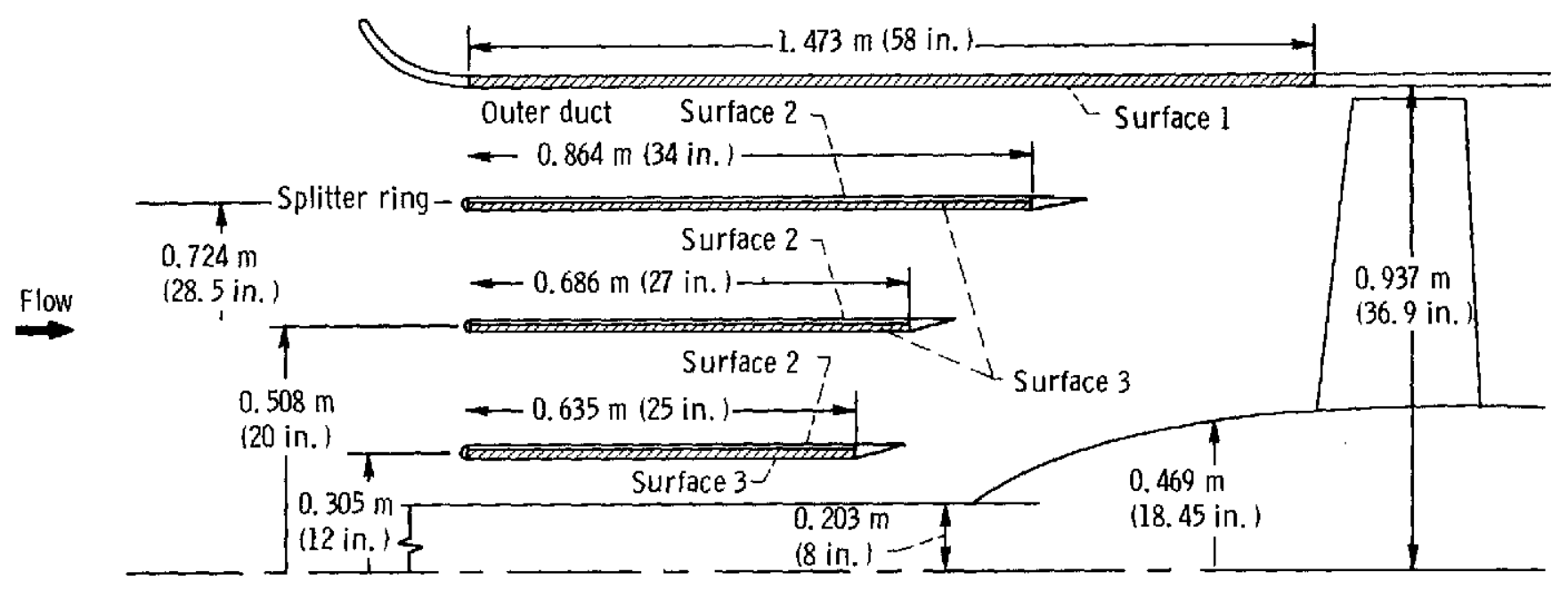

\begin{tabular}{|c|c|c|c|c|c|c|}
\hline \multirow[t]{2}{*}{$\begin{array}{l}\text { Sur- } \\
\text { face }\end{array}$} & \multirow{2}{*}{$\begin{array}{c}\text { Open } \\
\text { area, } \\
\text { percent }\end{array}$} & \multicolumn{2}{|c|}{$\begin{array}{l}\text { Perforated plate } \\
\text { hole diameter }\end{array}$} & \multicolumn{2}{|c|}{$\begin{array}{l}\text { Honeycomb } \\
\text { backing depth }\end{array}$} & \multirow{2}{*}{$\begin{array}{c}\text { Predicted } \\
\text { frequency of } \\
\text { maximum } \\
\text { noise } \\
\text { attenuation, } \\
\mathrm{Hz}\end{array}$} \\
\hline & & $\mathrm{mm}$ & in. & $\mathrm{cm}$ & in. & \\
\hline \multicolumn{7}{|c|}{ Inlet suppressor A } \\
\hline $\begin{array}{l}1 \\
2 \\
3\end{array}$ & $\begin{array}{l}8 \\
3.87 \\
8\end{array}$ & $\begin{array}{l}1.27 \\
1.27 \\
1.27\end{array}$ & $\begin{array}{r}0.050 \\
.050 \\
.050\end{array}$ & $\begin{array}{r}2.24 \\
.51 \\
1.73\end{array}$ & $\begin{array}{r}0.88 \\
.20 \\
.68\end{array}$ & $\begin{array}{l}1250 \\
3150 \\
1600\end{array}$ \\
\hline \multicolumn{7}{|c|}{ Inlet suppressor B } \\
\hline $\begin{array}{l}1 \\
2 \\
3\end{array}$ & $\begin{array}{l}2.5 \\
2.5 \\
2.5\end{array}$ & $\begin{array}{r}0.81 \\
.81 \\
.81\end{array}$ & $\begin{array}{r}0.032 \\
.032 \\
.032\end{array}$ & $\begin{array}{r}2.24 \\
.51 \\
1.73\end{array}$ & $\begin{array}{r}0.88 \\
.20 \\
.68\end{array}$ & $\begin{array}{l}1250 \\
3150 \\
1600\end{array}$ \\
\hline
\end{tabular}

(a) Inlet suppressor.

Figure 3. - Suppressor design details. Perforated plate sheet: thickness, 0.51 millimeter $(0.020 \mathrm{in}$.); material, aluminum. Honeycomb cell size, 0.95 centimeter ( $3 / 8$ in.) hexagon. (Not to scale.) 


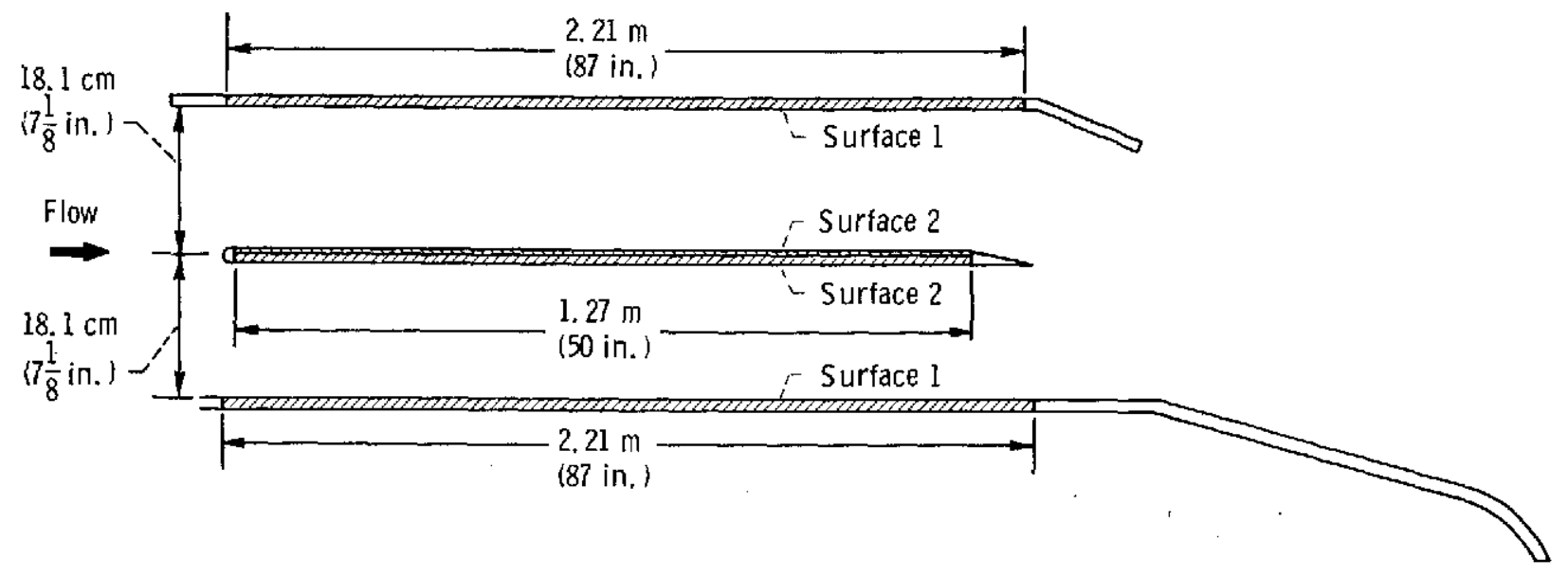

\begin{tabular}{|c|c|c|c|c|c|}
\hline \multirow{2}{*}{ Surface } & $\begin{array}{c}\text { Open area, } \\
\text { percent }\end{array}$ & $\begin{array}{c}\text { Perforated plate } \\
\text { hole diameter }\end{array}$ & \multicolumn{2}{|c|}{$\begin{array}{r}\text { Honeycomb backing } \\
\text { depth }\end{array}$} \\
\cline { 3 - 6 } & & $\mathrm{mm}$ & in. & $\mathrm{cm}$ & in. \\
\hline 1 & 8 & $\begin{array}{r}1.27 \\
2\end{array}$ & 0.050 & 2.24 & 0.88 \\
& 6.3 & 3.17 & .125 & .800 & .315 \\
\hline
\end{tabular}

(b) Exhaust suppressor.

Figure 3. - Concluded.

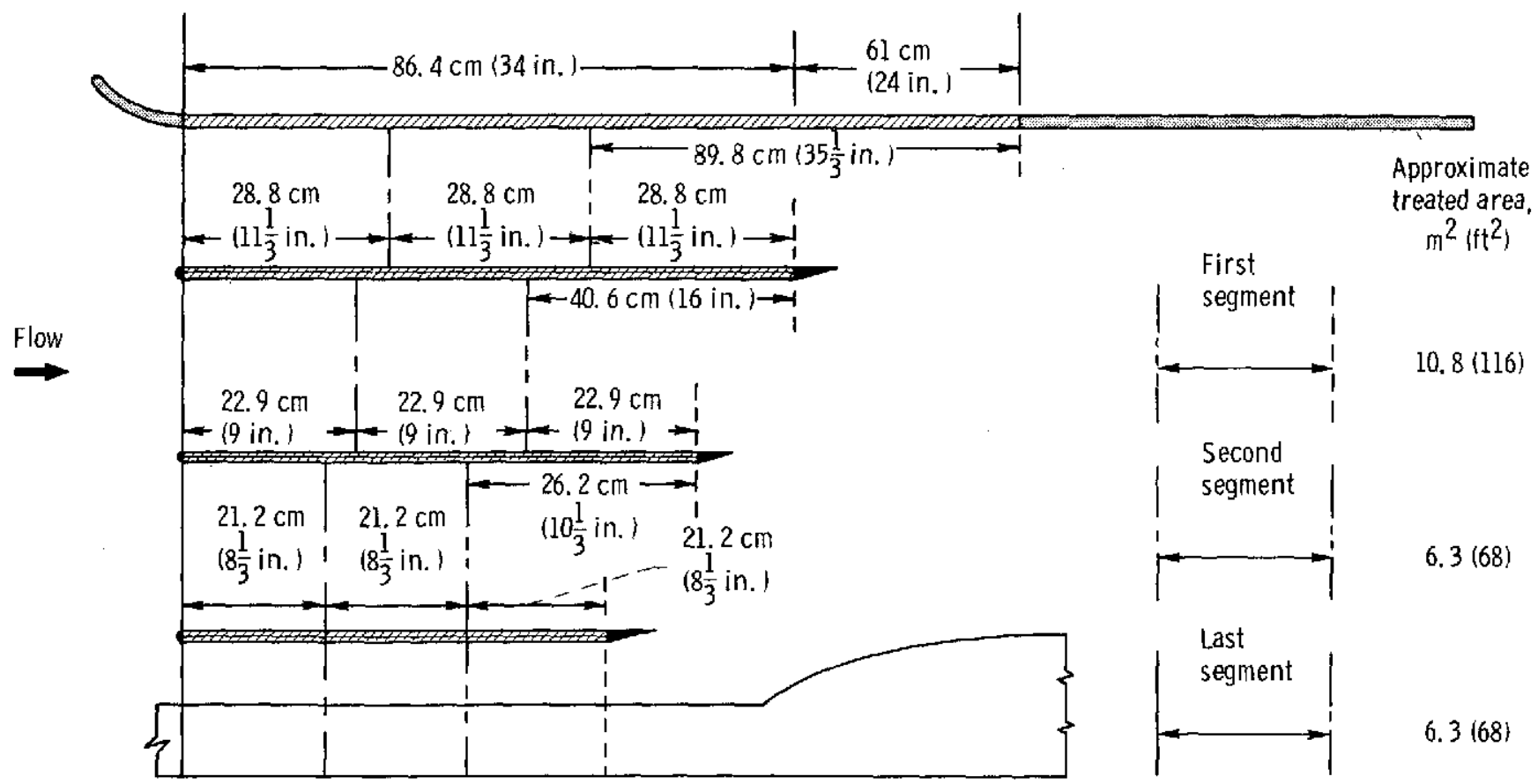

Figure 4. - Inlet suppressor length variation. (Not to scale.) 


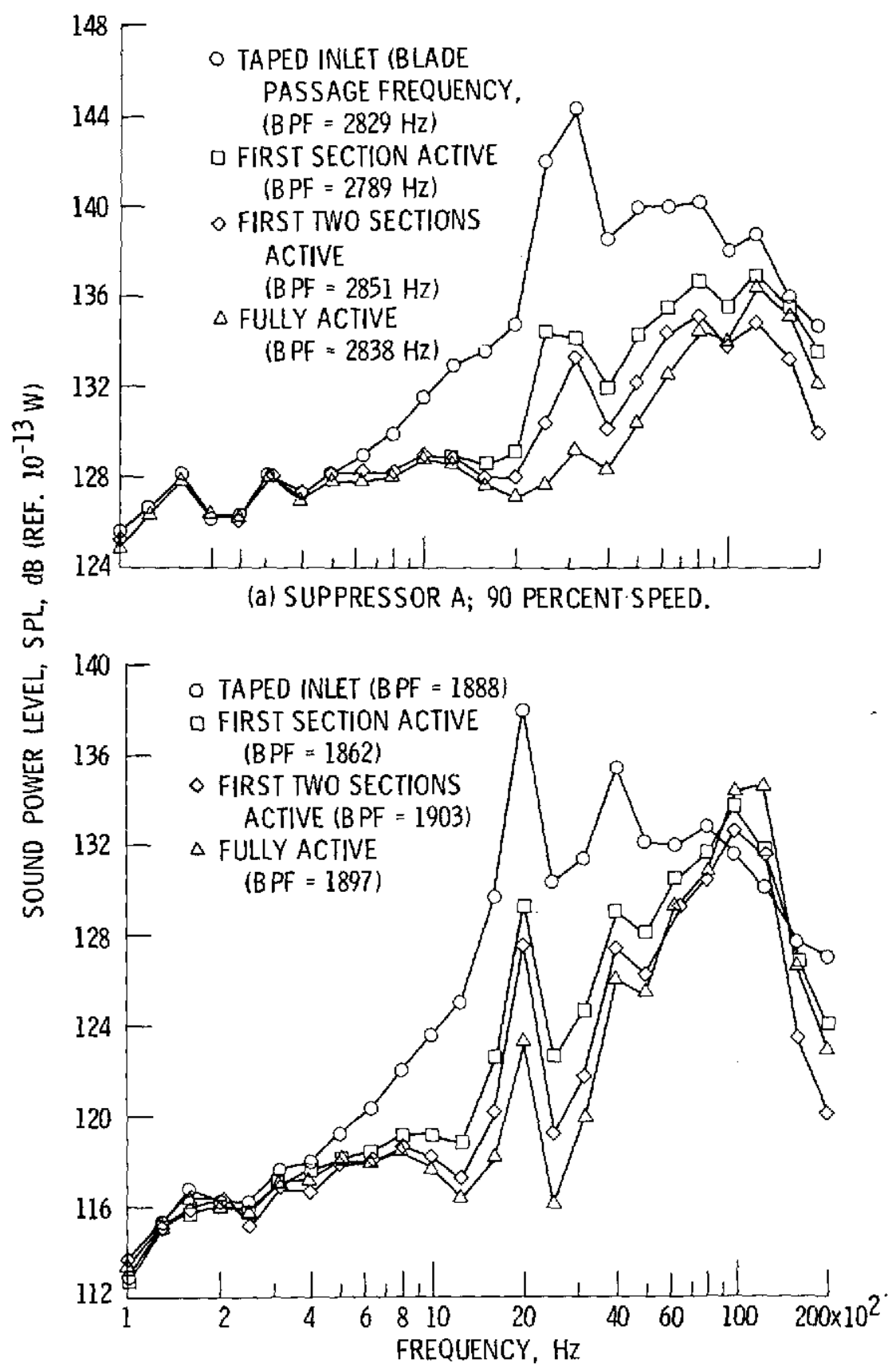

(b) SUPPRESSOR A; 60 PERCENT SPEED.

Figure 5. - Inlet hemisphere sound power level spectra. 


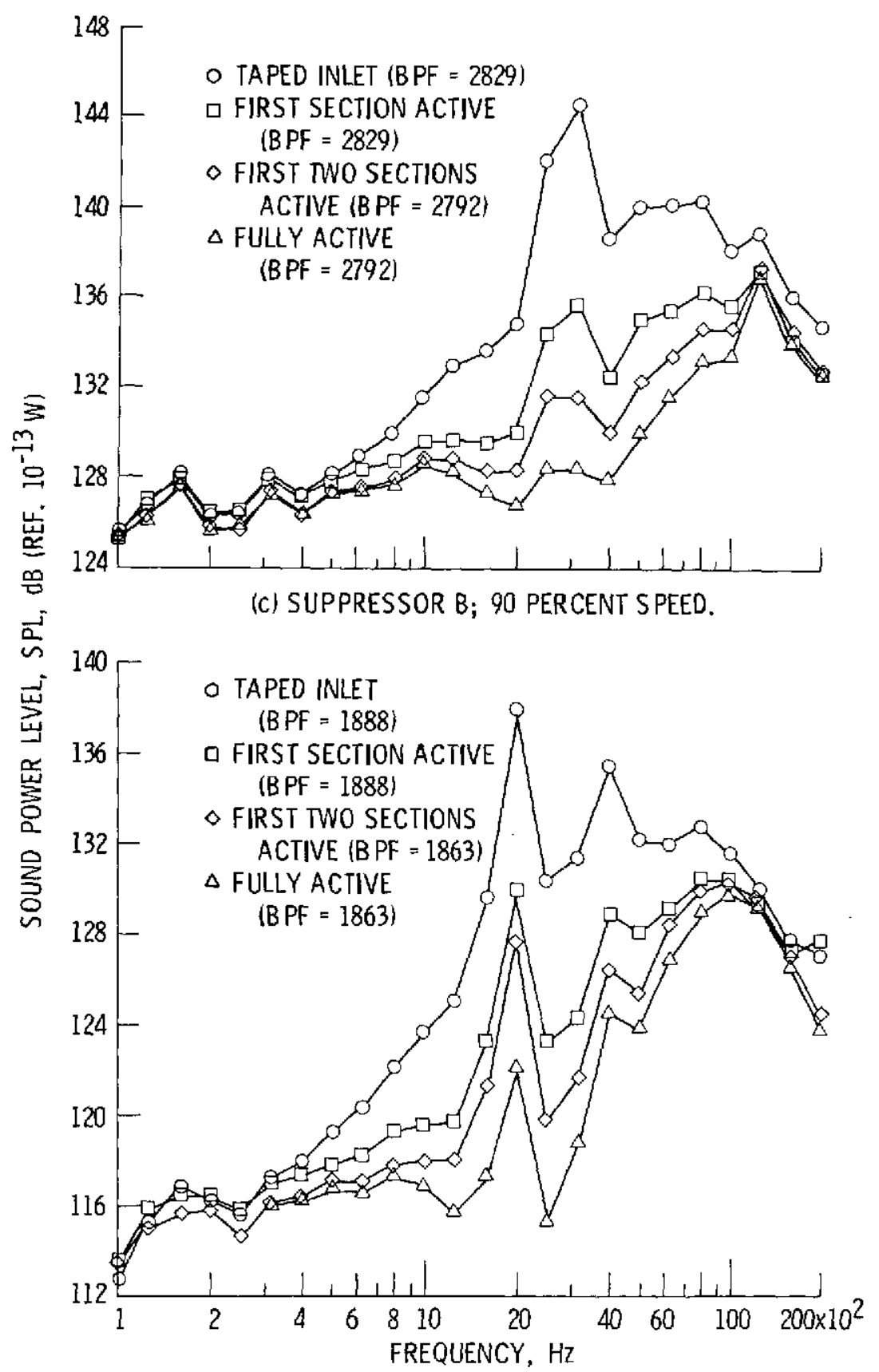

(d) SUPPRESSOR B; 60 PERCENT SPEED.

Figure 5. - Concluded. 


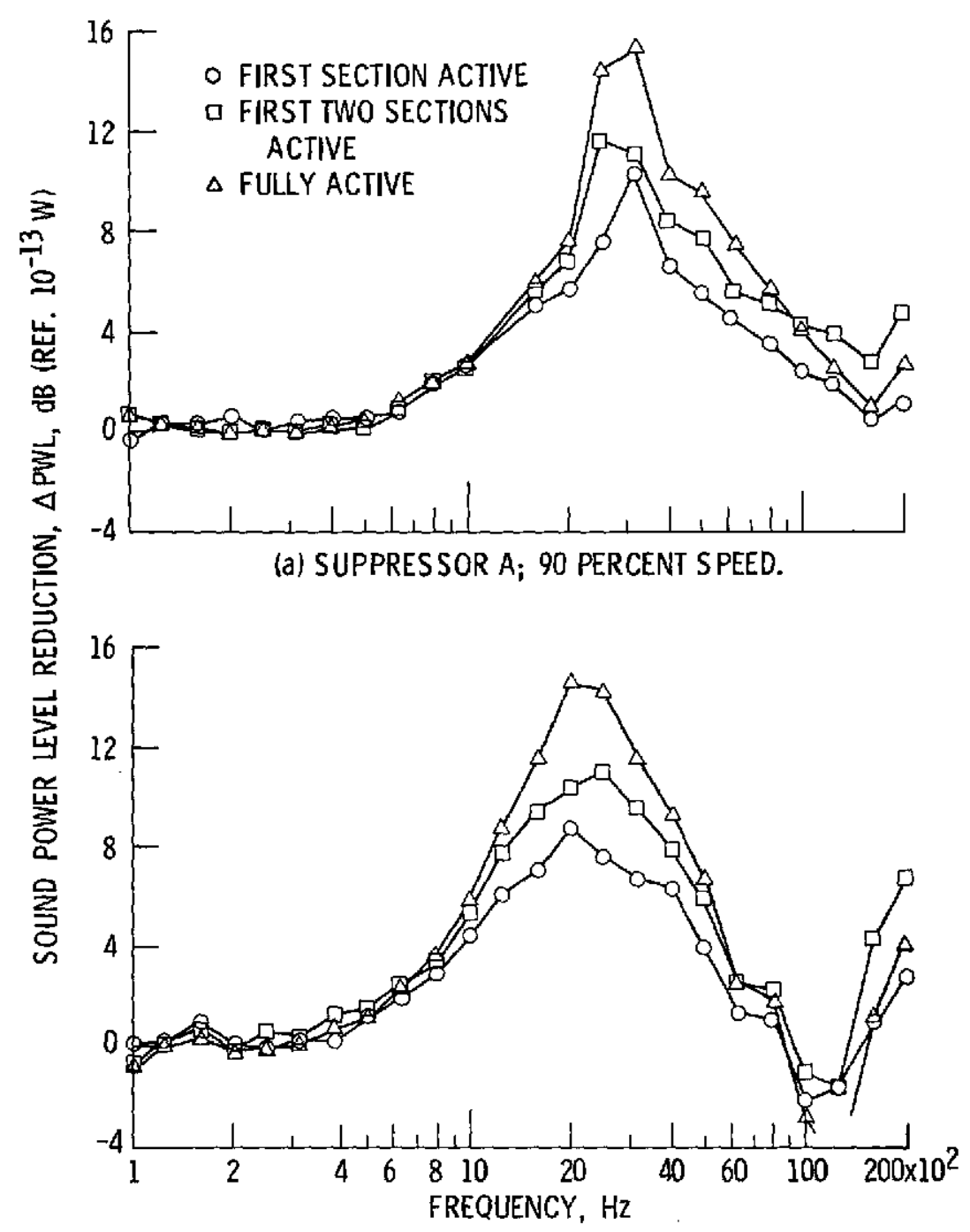

(b) SUPPRESSOR A; 60 PERCENT SPEED.

Figure 6. - Variation of inlet hemisphere sound power level attenuation spectra with treated length. 


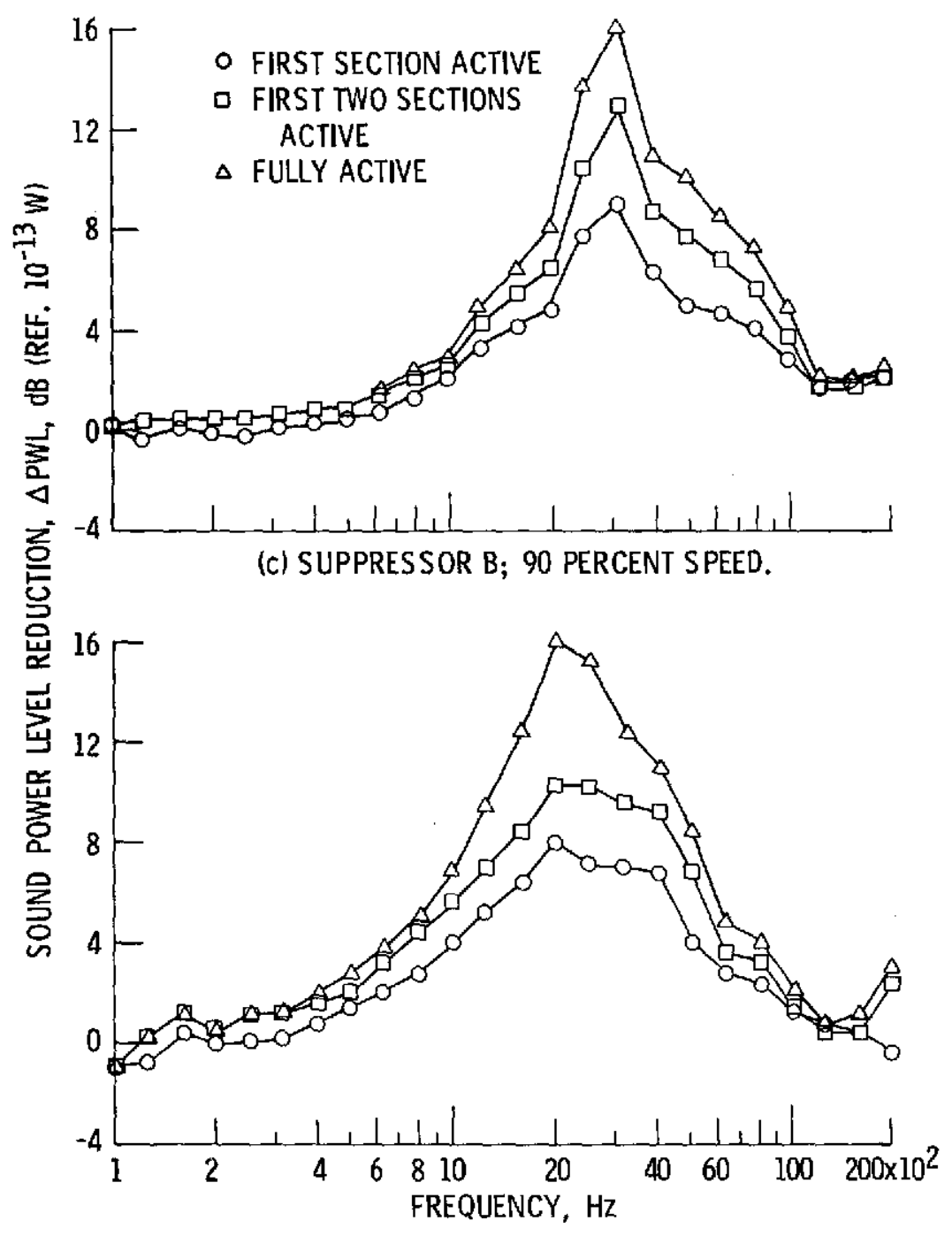

(d) SUPPRESSOR B; 60 PERCENT SPEED.

Figure 6. - Concluded. 


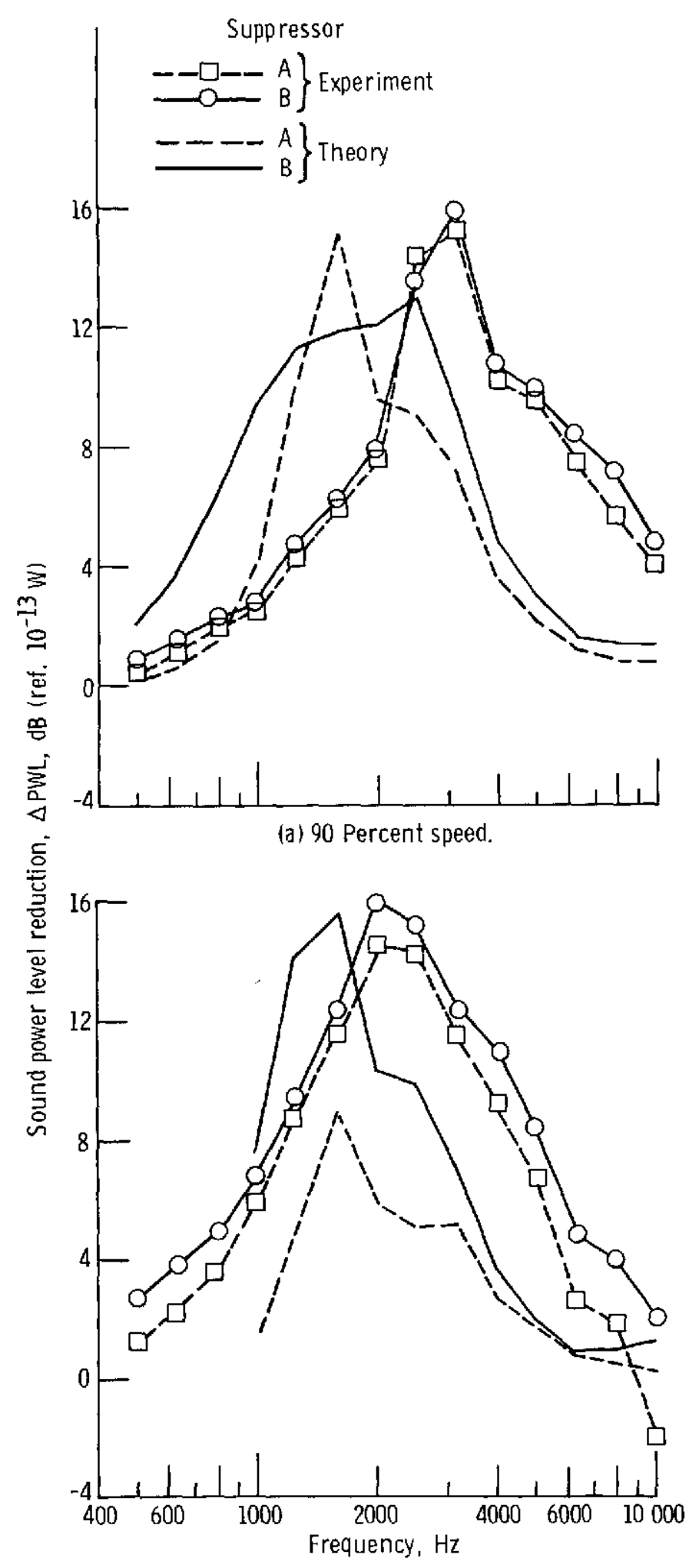

(b) 60 Percent speed.

Figure 7. - Comparison of inlet hemisphere sound power level attenuation with theory. Fully active treatment length. 


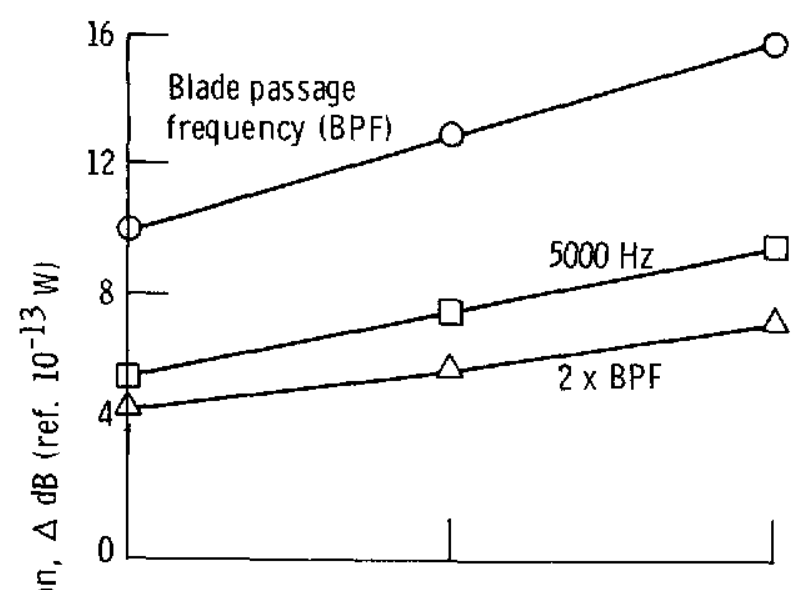

(a) Suppressor A; 90 percent speed.

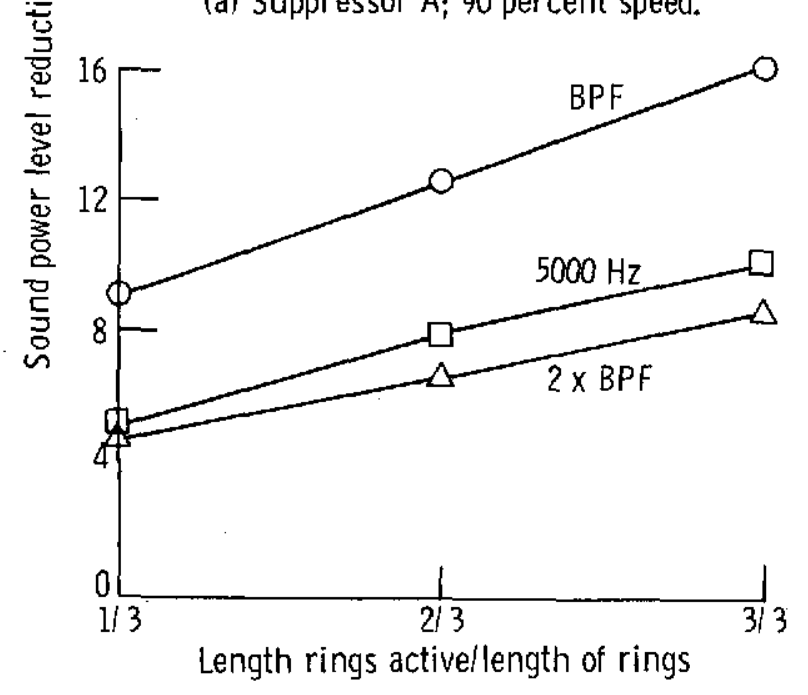

(b) Suppressor B; 90.percent speed.

Figure 8. - Variation of inlet hemisphere sound power level reduction with fraction of ring treatment length active.

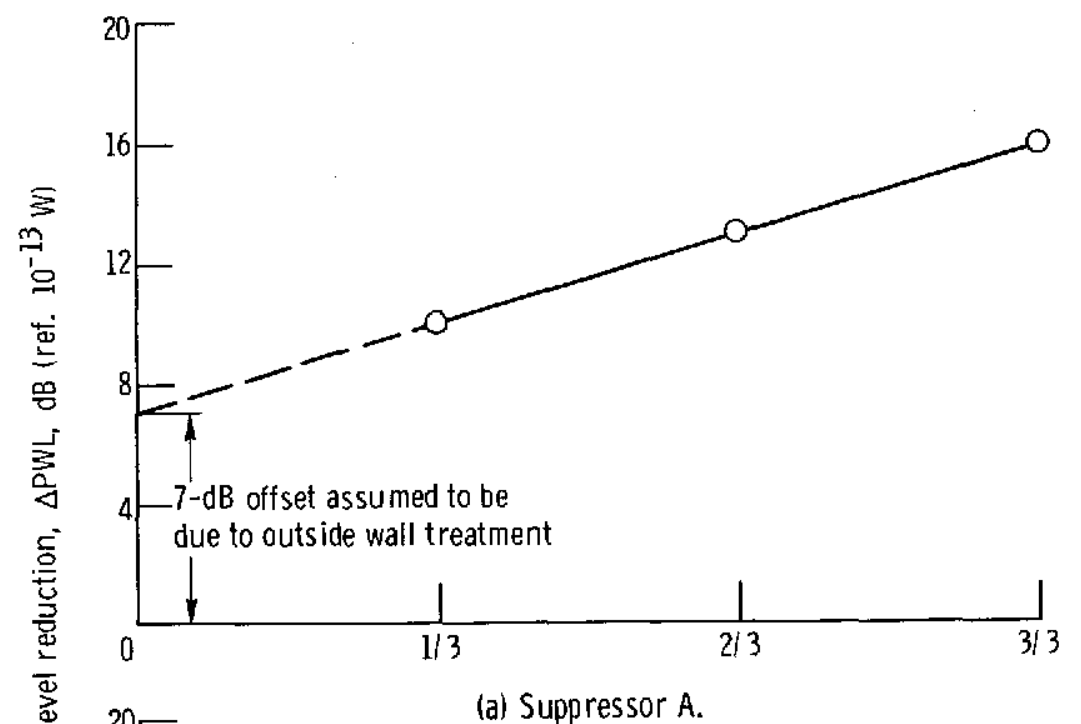

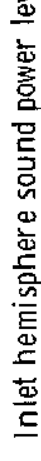

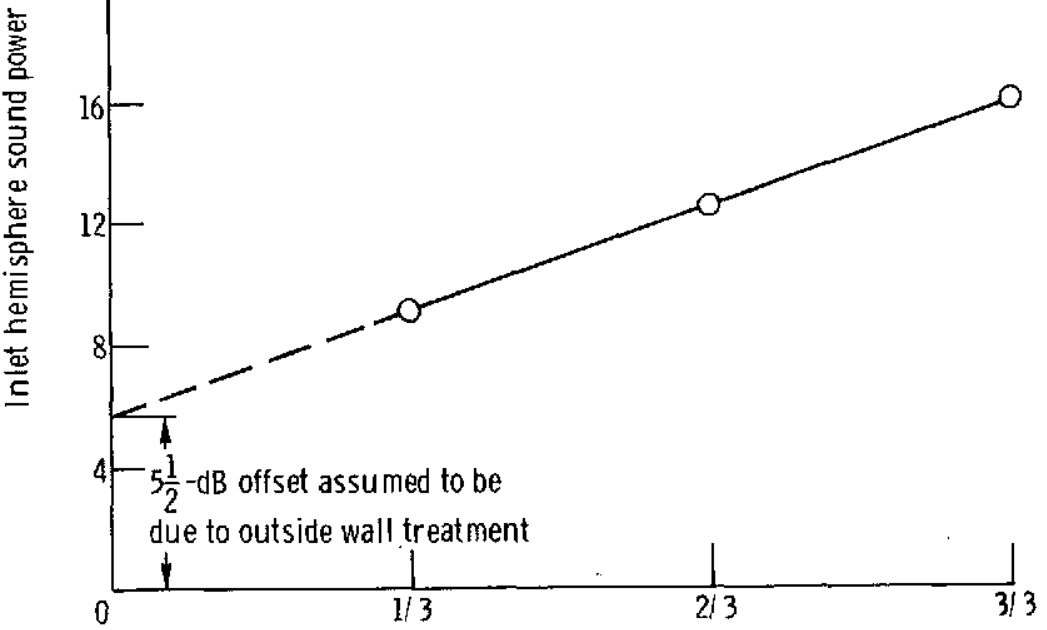

(Length of rings active)/(length of rings)

(b) Suppressor B.

Figure 9. - Extrapolation of blade passage frequency attenuation from ring section of liner to obtain attenuation attributed to outside wall treatment. (90 Percent speed.) 


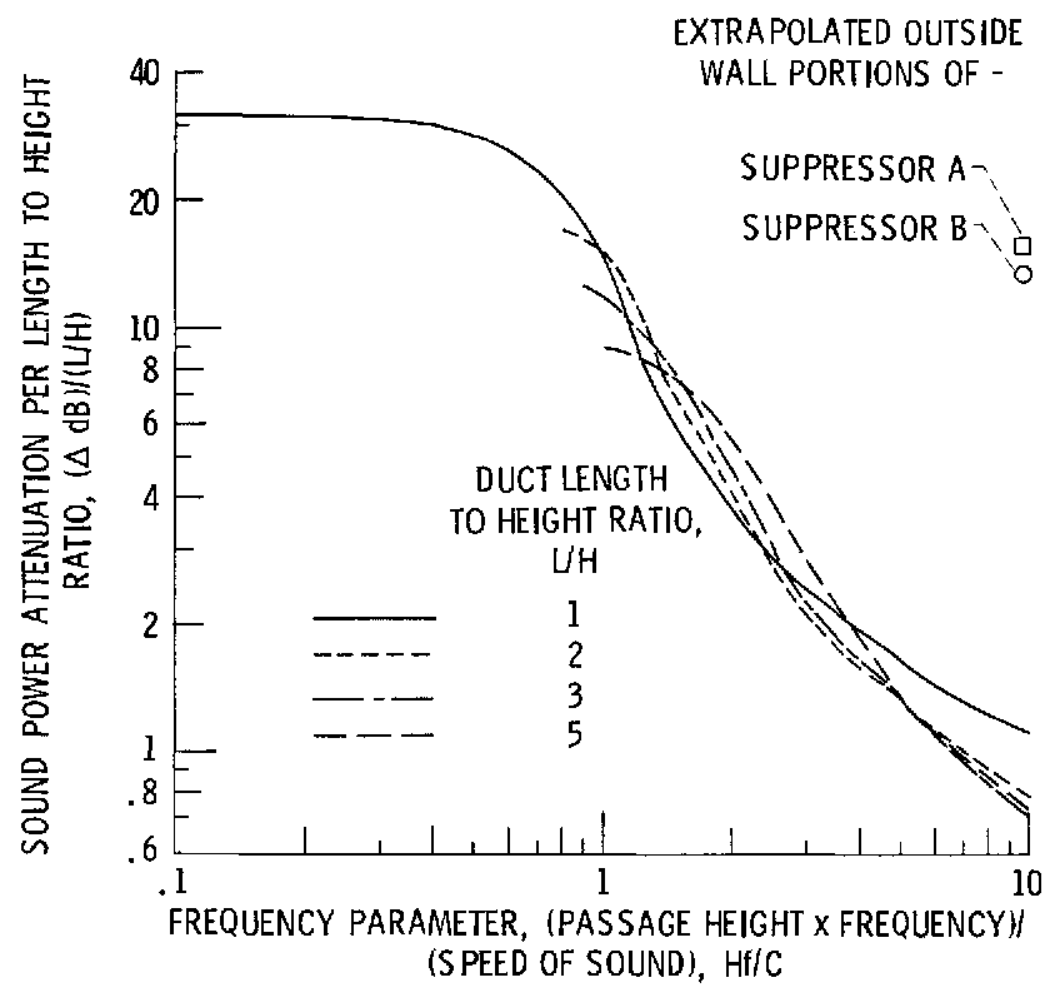

Figure 10. - Comparisons of sound power attenuations per passage length over height ratio with theoretical maximums. 


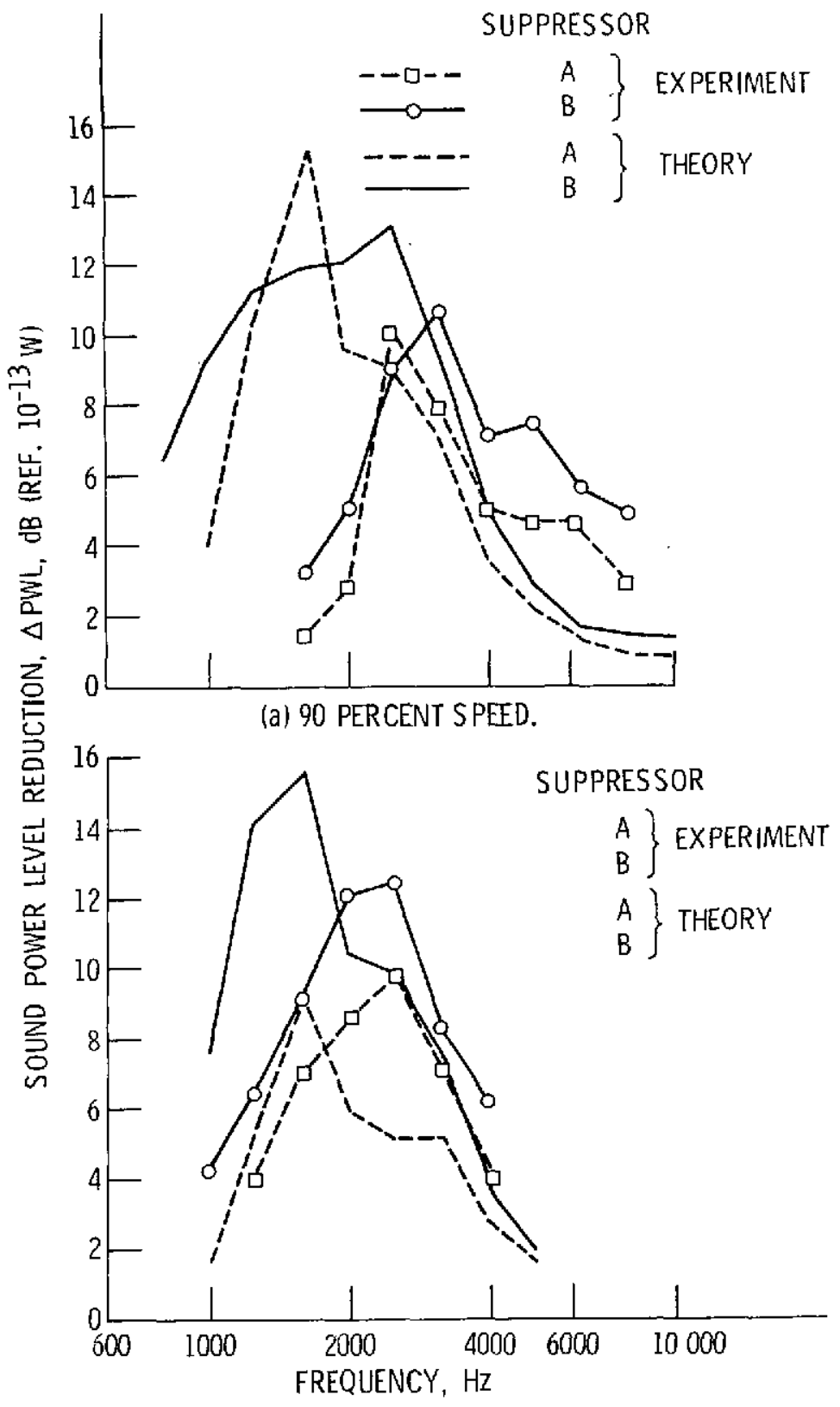

Figure 11. - Comparison of the extrapolated inlet hemisphere sound power level attenuation of the ringed portion of the suppressor with theory.

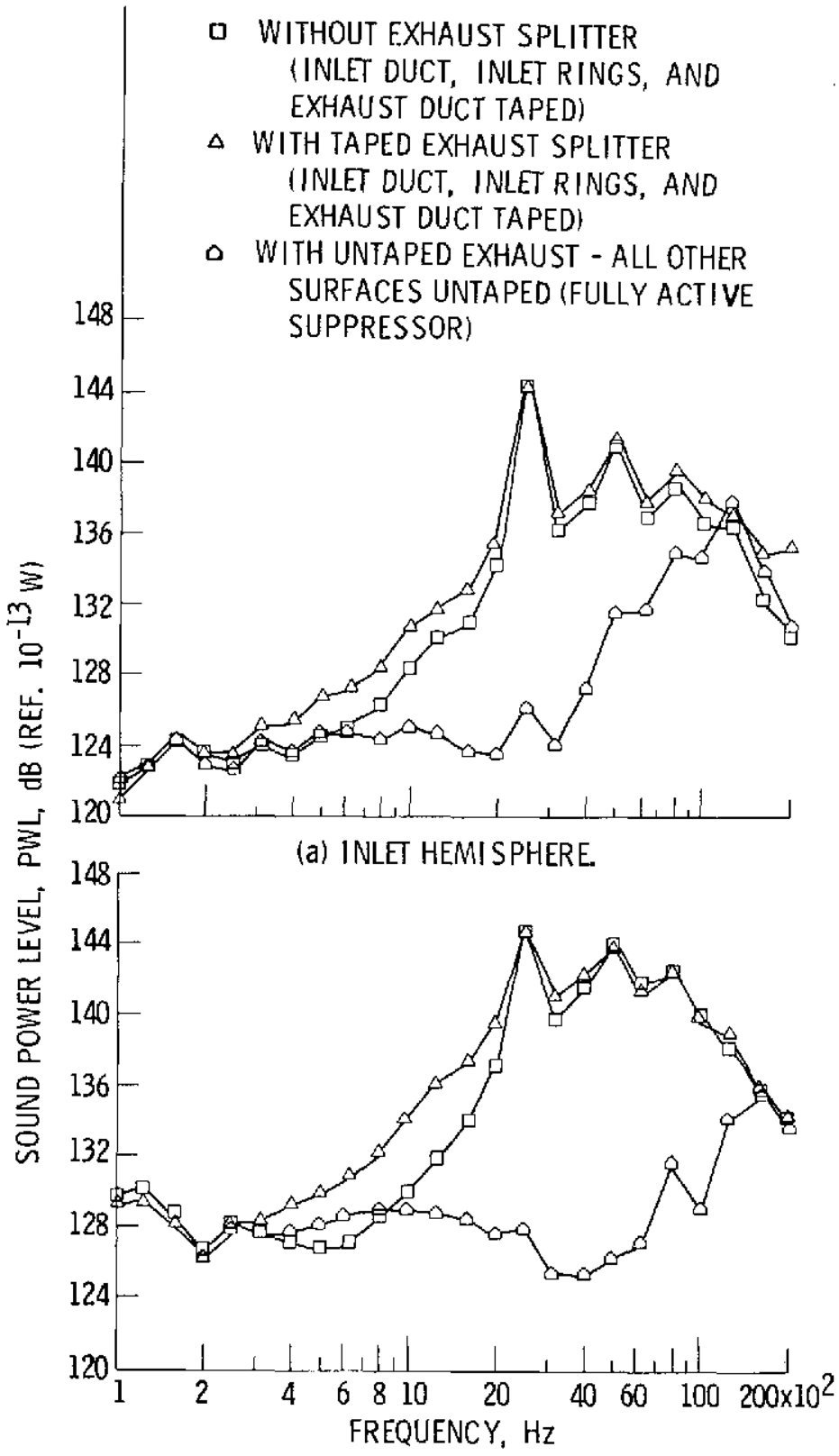

(b) EXHAUST HEMISPHERE.

Figure 12. - Effect of exhaust splitter ring on sound power level spectra at 80 percent speed. 